are appointed by the Secretary-General of the UN and the Director-General of UNESCO. Unlike a traditional university with a campus, students and faculty, it works through networks of collaborating institutions and individuals to undertake multidisciplinary research on problems of human survival, development and welfare; and to strengthen research and training capabilities in developing countries. It also provides postgraduate fellowships and $\mathrm{PhD}$ internships to scholars and scientists from developing countries. The University focuses its work within two programme areas: peace and governance, and environment and development.

Address: 5-53-70 Jingumae, Shibuya-ku, Tokyo 150-8925, Japan.

Website: http://www.unu.edu

United Nations Entity for Gender Equality and the Empowerment of Women (UN Women). Established in July 2010, UN Women supports international political negotiations to formulate globally agreed standards for gender equality and helps UN member states to implement those standards by providing expertise and financial support. It merges and builds on the work of four previously distinct parts of the UN system: the Division for the Advancement of Women (DAW), the International Research and Training Institute for the Advancement of Women (INSTRAW), the Office of the Special Adviser on Gender Issues and Advancement of Women (OSAGI) and the United Nations Development Fund for Women (UNIFEM).

Address: 405 East 42nd St., New York, NY 10017, USA.

Website: http://www.unwomen.org

Information. The UN Statistics Division in New York provides a wide range of statistical outputs and services for producers and users of statistics worldwide, facilitating national and international policy formulation, implementation and monitoring. It produces printed publications of statistics and statistical methods in the fields of international merchandise trade, national accounts, demography and population, gender, industry, energy, environment, human settlements and disability, as well as general statistics compendiums including the Statistical Yearbook and World Statistics Pocketbook. Many of its databases are available on $\mathrm{CD}-\mathrm{ROM}$ and the internet.

Website: http://unstats.un.org

UN Information Centre. Public Inquiries Unit, Department of Public Information, Room GA-57, United Nations Plaza, New York, NY 10017. There are also 63 UN Information Centres in other parts of the world.

Website: http://www.un.org

\section{Specialized Agencies of the UN}

The intergovernmental agencies related to the UN by special agreements are separate autonomous organizations which work with the UN and each other through the co-ordinating machinery of the Economic and Social Council. Of these, 19 are 'Specialized Agencies' within the terms of the UN Charter, and report annually to ECOSOC.

\section{Food and Agriculture Organization of the United Nations (FAO)}

Origin. In 1943 the International Conference on Food and Agriculture, at Hot Springs, Virginia, set up an Interim Commission, based in Washington, with a remit to establish an organization. Its Constitution was signed on 16 Oct. 1945 in Quebec City. Today, membership totals 192 countries. The European Union was made a member as a 'regional economic integration organization' in 1991.

Aims and Activities. The aims of FAO are to raise levels of nutrition and standards of living; to improve the production and distribution of all food and agricultural products from farms, forests and fisheries; to improve the living conditions of rural populations; and, by these means, to eliminate hunger. Its priority objectives are to encourage sustainable agriculture and rural development as part of a long-term strategy for the conservation and management of natural resources; and to ensure the availability of adequate food supplies, by maximizing stability in the flow of supplies and securing access to food by the poor.

In carrying out these aims, FAO promotes investment in agriculture, better soil and water management, improved yields of crops and livestock, agricultural research and the transfer of technology to developing countries; and encourages the conservation of natural resources and rational use of fertilizers and pesticides; the development and sustainable utilization of marine and inland fisheries; the sustainable management of forest resources and the combating of animal disease. Technical assistance is provided in all of these fields, and in nutrition, agricultural engineering, agrarian reform, development communications, remote sensing for climate and vegetation, and the prevention of post-harvest food losses. In addition, FAO works to maintain global biodiversity with the emphasis on the genetic diversity of crop plants and domesticated animals; and plays a major role in the collection, analysis and dissemination of information on agricultural production and commodities. Finally, FAO acts as a neutral forum for the discussion of issues, and advises governments on policy, through international conferences like the World Food Summit in 1996, the World Food Summit: five years later in 2002 and the World Summit on Food Security in 2009, all held in Rome.

Special FAO programmes help countries prepare for, and provide relief in the event of, emergency food situations, in particular through the rehabilitation of agriculture after disasters. The Special Programme for Food Security, launched in 1994, is designed to assist target countries to increase food production and productivity as rapidly as possible, primarily through the widespread adoption by farmers of available improved production technologies, with the emphasis on high-potential areas. FAO provides support for the global co-ordination of the programme and helps attract funds. The Emergency Prevention System for Transboundary Animal and Plant Pests and Diseases (EMPRES), established in 1994, strengthens FAO's existing contribution to the prevention, control and eradication of diseases and pests before they compromise food security, with locusts and rinderpest among its priorities. The Global Information and Early Warning System (GIEWS) provides current information on the world food situation and identifies countries threatened by shortages to guide potential donors. The interagency Food Insecurity and Vulnerability Information and Mapping System initiative (FIVIMS) was established in 1997, with FAO as its secretariat. Together with the UN, FAO sponsors the World Food Programme (WFP).

Finance. The budget for the $2012-13$ biennium is US $\$ 1,005 \cdot 6 \mathrm{~m}$. FAO's Regular Programme budget, financed by contributions from member governments, covers the cost of its secretariat and Technical Co-operation Programme (TCP), and part of the costs of several special programmes.

FAO continues to provide technical advice and support through its field programmes in all areas of food and agriculture, fisheries, forestry and rural development. In 2009 FAO-assisted projects used US $\$ 647 \cdot 1 \mathrm{~m}$. from donor agencies and governments for agricultural and rural development projects and emergencies. 
Some $82 \cdot 1 \%$ of Field Programme finances were taken from national trust funds. In the same year, FAO itself contributed $9.2 \%$ (or US $\$ 66.4 \mathrm{~m}$.), provided by the Regular Programme budget through its Technical Co-operation Programme and its national and regional programmes for food security. The FAO Investment Centre organizes more than 600 field missions for 140 investment projects in around 100 countries.

Organization. The FAO Conference, composed of all members, meets every other year to determine policy and approve the FAO's budget and programme. The 49-member Council, elected by the Conference, serves as FAO's governing body between conference sessions. Much of its work is carried out by dozens of regional or specialist commissions, such as the Asia-Pacific Fishery Commission, the European Commission on Agriculture and the Commission on Plant Genetic Resources. The Director-General is elected for a renewable six-year term.

\section{Headquarters: Viale delle Terme di Caracalla, 00153 Rome, \\ Italy. \\ Website: http://www.fao.org \\ Director-General: José Graziano da Silva (Brazil).}

Publications. Unasylva (quarterly), 1947 ff.; The State of Food and Agriculture (annual), 1947 ff.; Animal Health Yearbook (annual), 1957 ff.; Statistical Yearbook (annual), 2004 ff.; FAO Commodity Review (annual), 1961 ff.; Yearbook of Forest Products (annual), 1947 ff.; Yearbook of Fishery Statistics (in two volumes); FAO Plant Protection Bulletin (quarterly); Environment and Energy Bulletin; Food Outlook (monthly); The State of World Fisheries and Aquaculture (annual); The State of the World's Forests; World Watch List for Domestic Animal Diversity; The State of Food Insecurity in the World.

\section{International Bank for Reconstruction and Development (IBRD) - The World Bank}

Origin. Conceived at the UN Monetary and Financial Conference at Bretton Woods (New Hampshire, USA) in July 1944, the IBRD, frequently called the World Bank, began operations in June 1946, its purpose being to provide funds, policy guidance and technical assistance to facilitate economic development in its poorer member countries. The Group comprises four other organizations: the International Development Association (IDA), which provides interest-free loans and grants to governments of the poorest countries; the International Finance Corporation (IFC), which provides loans, equity and technical assistance to stimulate private sector investment in developing countries; the Multilateral Investment Guarantee Agency (MIGA), which provides guarantees against losses caused by non-commercial risks to investors in developing countries; and the International Centre for Settlement of Investment Disputes (ICSID), which provides international facilities for conciliation and arbitration of investment disputes.

Members. Afghanistan, Albania, Algeria, Angola, Antigua and Barbuda, Argentina, Armenia, Australia, Austria, Azerbaijan, Bahamas, Bahrain, Bangladesh, Barbados, Belarus, Belgium, Belize, Benin, Bhutan, Bolivia, Bosnia and Herzegovina, Botswana, Brazil, Brunei, Bulgaria, Burkina Faso, Burundi, Cambodia, Cameroon, Canada, Cape Verde, Central African Republic, Chad, Chile, China, Colombia, Comoros, Democratic Republic of the Congo, Republic of the Congo, Costa Rica, Côte d'Ivoire, Croatia, Cyprus, Czech Republic, Denmark, Djibouti, Dominica, Dominican Republic, Ecuador, Egypt, El Salvador, Equatorial Guinea, Eritrea, Estonia, Ethiopia, Fiji Islands, Finland, France, Gabon, Gambia, Georgia, Germany, Ghana, Greece, Grenada, Guatemala, Guinea, Guinea-Bissau, Guyana, Haiti, Honduras, Hungary, Iceland, India, Indonesia, Iran, Iraq, Ireland, Israel, Italy, Jamaica, Japan, Jordan, Kazakhstan, Kenya, Kiribati, South Korea, Kosovo, Kuwait, Kyrgyzstan, Laos, Latvia, Lebanon, Lesotho, Liberia, Libya, Lithuania, Luxembourg, Macedonia,
Madagascar, Malawii, Malaysia, Maldives, Mali, Malta, Marshall Islands, Mauritania, Mauritius, Mexico, Micronesia, Moldova, Mongolia, Montenegro, Morocco, Mozambique, Myanmar, Namibia, Nepal, Netherlands, New Zealand, Nicaragua, Niger, Nigeria, Norway, Oman, Pakistan, Palau, Panama, Papua New Guinea, Paraguay, Peru, Philippines, Poland, Portugal, Qatar, Romania, Russia, Rwanda, St Kitts and Nevis, St Lucia, St Vincent and the Grenadines, Samoa, San Marino, São Tomé e Príncipe, Saudi Arabia, Senegal, Serbia, Seychelles, Sierra Leone, Singapore, Slovakia, Slovenia, Solomon Islands, Somalia, South Africa, South Sudan, Spain, Sri Lanka, Sudan, Suriname, Swaziland, Sweden, Switzerland, Syria, Tajikistan, Tanzania, Thailand, Timor-Leste, Togo, Tonga, Trinidad and Tobago, Tunisia, Turkey, Turkmenistan, Tuvalu, Uganda, Ukraine, United Arab Emirates, UK, USA, Uruguay, Uzbekistan, Vanuatu, Venezuela, Vietnam, Yemen, Zambia, Zimbabwe.

Activities. The Bank obtains its funds from the following sources: capital paid in by member countries; sales of its own securities; sales of parts of its loans; repayments; and net earnings. A resolution of the Board of Governors of 27 April 1988 provides that the paid-in portion of the shares authorized to be subscribed under it will be $3 \%$.

The Bank is self-supporting, raising most of its money on the world's financial markets. In the fiscal year ending 30 June 2012 it achieved an operating income of US $\$ 783 \mathrm{~m}$. Income totalled US $\$ 4 \cdot 3 \mathrm{bn}$. and expenditure US $\$ 3 \cdot 6 \mathrm{bn}$.

In the fiscal year 2012 the Bank lent US\$20.7bn. for 93 new operations. Cumulative lending had totalled US $\$ 400 \mathrm{bn}$. by June 2012. In order to eliminate wasteful overlapping of development assistance and to ensure that the funds available are used to the best possible effect, the Bank has organized consortia or consultative groups of aid-giving nations for many countries. These include Bangladesh, Belarus, Bolivia, Bulgaria, Egypt, Ethiopia, Jordan, Kazakhstan, Kenya, Kyrgyzstan, Macedonia, Malaŵi, Mauritania, Moldova, Mozambique, Nicaragua, Pakistan, Peru, Romania, Sierra Leone, Tanzania, the [Palestinian] West Bank and Gaza Strip, Zambia, Zimbabwe and the Caribbean Group for Co-operation in Economic Development.

For the purposes of its analytical and operational work, in 2012 the IBRD characterized economies as follows: low income (average annual per capita gross national income of $\$ 1,025$ or less); lower middle income (between $\$ 1,026$ and $\$ 4,035$ ); upper middle income (between $\$ 4,036$ and $\$ 12,475$ ); and high income $(\$ 12,476$ or more).

A wide variety of technical assistance is at the core of IBRD's activities. It acts as executing agency for a number of preinvestment surveys financed by the UN Development Programme. Resident missions have been established in 64 developing member countries and there are regional offices for East and West Africa, the Baltic States and South-East Asia, which assist in the preparation and implementation of projects. The Bank maintains a staff college, the World Bank Institute in Washington, D.C., for senior officials of member countries.

Access to Information. Effective 1 July 2010, the World Bank Policy on Access to Information marked a pivotal shift in the World Bank's approach to making information available to the public. Now the public can obtain more information about projects under preparation, projects under implementation, analytic and advisory activities, and Board proceedings. The policy also includes a clear process for making information publicly available and a right to appeal if information seekers believe they were improperly or unreasonably denied access to information or there is a public interest case to override an exception that restricts certain information.

Organization. As of Feb. 2013 the Bank had 188 members, each with voting power in the institution, based on shareholding which in turn is based on a country's economic growth. The president 
is selected by the Bank's Board of Executive Directors. The Articles of Agreement do not specify the nationality of the president but by custom the US Executive Director makes a nomination, and by a long-standing, informal agreement, the president is a US national (while the managing director of the IMF is European). The initial term is five years, with a second of five years or less.

\section{Current Leaders}

Jim Yong Kim

\section{Position}

President

\section{Introduction}

Jim Yong Kim, a medical scientist and anthropologist, became president of the World Bank in July 2012. He is the first development professional to hold the post and has signalled his support for pursuing private enterprise growth alongside environmental sustainability and social protection.

\section{Early Life}

Jim Yong Kim was born on 8 Dec. 1959 in Seoul, South Korea, but moved to the USA aged five and became an American citizen. Transferring from Iowa University, he graduated in biology from Brown University in 1982. He received his medical degree in 1991 and $\mathrm{PhD}$ in anthropology in 1993, both from Harvard.

In 1987 he co-founded Partners in Health (PIH), a non-profit organization pioneering community-based health care programmes in low-income areas and developing countries. Working initially in Boston and Haiti, Kim steered the expansion of PIH into Peru in the 1990s. Its success in treating a range of diseases was widely recognized and its model later adopted by the World Health Organization (WHO).

In $2003 \mathrm{Kim}$ stepped down as executive director of PIH to become director of the WHO's HIV/AIDS department, where he led the ' 3 by 5 ' initiative to treat $3 \mathrm{~m}$. new HIV/AIDS patients in developing countries with antiretroviral drugs by 2005 . The programme was credited with greatly accelerating the provision of effective HIV/AIDS treatment and reached its target in 2007.

Kim has held a range of teaching and research posts at Harvard since 1993. In 2006 the University appointed him chair of its department of social medicine (later renamed the department of global health and social medicine), where he developed a global health delivery programme. He has also served as head of the François-Xavier Bagnoud Center for Health and Human Rights at the Harvard School of Public Health, and as chief of the Brigham and Women's Hospital Division of Social Medicine and Health Inequalities.

In $2009 \mathrm{Kim}$ left Harvard to become president of Dartmouth College, where he established a centre for health care delivery science. In March 2012 President Obama nominated him for the presidency of the World Bank and in April 2012 he beat two rivals in an election for the post. Both his opponents-the Nigerian finance minister, Ngozi Okonjo-Iweala, and a Colombian economist, José Antonio Ocampo-had argued that the president should be from a developing nation.

\section{Career in Office}

Kim took office on 1 July 2012. In Nov. 2012 he identified tackling climate change as crucial to ending poverty, announcing that the World Bank would integrate environmental sustainability into future development plans. Achieving this while promoting economic growth in emerging nations is set to be his key challenge.

European office: 66 avenue d'Iéna, 75116 Paris, France. London office: Milbank Tower, 12th Floor, 21-24 Milbank, London SW1P 4QP, England. Tokyo office: 10th Floor, Fukoku Seimei Building, 2-2-2 Uchisaiwai-cho, Chiyoda-ku, Tokyo 100-0011 Japan.
Headquarters: 1818 H St., NW, Washington, D.C., 20433, USA. Website: http://www.worldbank.org

President: Jim Yong Kim (USA).

Publications. World Bank Annual Report; Summary Proceedings of Annual Meetings; The World Bank and International Finance Company, 1986; The World Bank Atlas (annual); Catalog of Publications, 1986 ff.; World Development Report (annual); World Bank Economic Review (thrice yearly); World Bank and the Environment (annual); World Bank News (weekly); World Bank Research Observer; World Tables (annual); Social Indicators of Development (annual); ICSID Annual Report; ICSID Review: Foreign Investment Law Journal (twice yearly); Research News (quarterly).

\section{Further Reading}

Phillips, David A., Reforming the World Bank: Twenty Years of Trial - and Error. 2011

The World Bank, A Guide to the World Bank. 3rd ed. 2011

$\mathrm{Xu}$, Yi-Chong and Weller, Patrick, Inside the World Bank: Exploding the Myth of the Monolithic Bank. 2009

\section{International Development Association (IDA)}

A lending agency established in 1960 and administered by the IBRD to provide assistance on concessional terms to the poorest developing countries. Its resources consist of subscriptions and general replenishments from its more industrialized and developed members, special contributions and transfers from the net earnings of IBRD. Officers and staff of the IBRD serve concurrently as officers and staff of the IDA at the World Bank headquarters.

In fiscal year 2012 IDA commitments totalled US\$14.8bn.; new commitments totalled 160 new operations. Since 1960 IDA has lent US\$255bn. to 108 countries.

Headquarters: 1818 H St., NW, Washington, D.C., 20433, USA. Website: http://www.worldbank.org/ida

President: Jim Yong Kim (USA).

\section{International Finance Corporation (IFC)}

Established in 1956 to help strengthen the private sector in developing countries, through the provision of long-term loans, equity investments, quasi-equity instruments, standby financing, and structured finance and risk management products. It helps to finance new ventures and assist established enterprises as they expand, upgrade or diversify. In partnership with other donors, it provides a variety of technical assistance and advisory services to public and private sector clients. To be eligible for financing, projects must be profitable for investors, must benefit the economy of the country concerned, and must comply with IFC's environmental and social guidelines.

The majority of its funds are borrowed from the international financial markets through public bond issues or private placements. Its authorized capital is US\$2.58bn.; total capital at 30 June 2012 was US $\$ 20 \cdot 6 \mathrm{bn}$. IFC committed US $\$ 20 \cdot 4 \mathrm{bn}$. in total financing in fiscal year 2012 and committed 560 projects in 103 countries. It has 184 members.

Headquarters: 2121 Pennsylvania Ave., NW, Washington, D.C., 20433, USA.

Website: http://www.ifc.org

President: Jim Yong Kim (USA).

Publications. Annual Reports; Lessons of Experience (series); Paths Out of Poverty.

\section{Multilateral Investment Guarantee Agency (MIGA)}

Established in 1988 to encourage the flow of foreign direct investment to, and among, developing member countries, MIGA is the insurance arm of the World Bank. It provides investors with 
investment guarantees against non-commercial risk, such as expropriation and war, and gives advice to governments on improving climate for foreign investment. It may insure up to $90 \%$ of an investment, with a current limit of US\$50m. per project. In March 1999 the Council of Governors adopted a resolution for a capital increase for the Agency of approximately US\$850m. In addition US $\$ 150 \mathrm{~m}$. was transferred to MIGA by the World Bank as operating capital. In Feb. 2013 it had 175 member countries. Like IDA and ICSID, it is located at the World Bank headquarters in Washington (see above).

Headquarters: 1818 H St., NW, Washington, D.C., 20433, USA.

Website: http://www.miga.org

President: Jim Yong Kim (USA).

\section{International Centre for Settlement of Investment Disputes (ICSID)}

Founded in 1966 to promote increased flows of international investment by providing facilities for the conciliation and arbitration of disputes between governments and foreign investors. The Centre does not engage in such conciliation or arbitration. This is the task of conciliators and arbitrators appointed by the contracting parties, or as otherwise provided for in the Convention. Recourse to conciliation and arbitration by members is entirely voluntary.

In Feb. 2013 its Convention had 158 signatory countries. 251 cases had been concluded by it and 169 were pending. Disputes involved a variety of investment sectors: agriculture, banking, construction, energy, health, industrial, mining and tourism.

ICSID also undertakes research, publishing and advisory activities in the field of foreign investment law. Like IDA and MIGA, it is located at the World Bank headquarters in Washington (see above).

Headquarters: 1818 H St., NW, MSN U3-301, Washington, D.C., 20433, USA.

Website: http://www.worldbank.org/icsid

President: Jim Yong Kim (USA).

Secretary-General: Meg Kinnear (Canada).

Publications. ICSID Annual Report; News from ICSID; ICSID Review: Foreign Investment Law Journal; Investment Laws of the World; Investment Treaties.

\section{Further Reading}

Stone, D. L. and Wright, C., The World Bank and Governance. 2006 Woods, N., The Globalizers: The IMF, the World Bank and Their Borrowers. 2007

\section{International Civil Aviation Organization (ICAO)}

Origin. The Convention providing for the establishment of the ICAO was drawn up by the International Civil Aviation Conference held in Chicago in 1944. A Provisional International Civil Aviation Organization (PICAO) operated for 20 months until the formal establishment of ICAO on 4 April 1947. The Convention on International Civil Aviation superseded the provisions of the Paris Convention of 1919 and the Pan American Convention on Air Navigation of 1928.

Functions. It assists international civil aviation by establishing technical standards for safety and efficiency of air navigation and promoting simpler procedures at borders; develops regional plans for ground facilities and services needed for international flying; disseminates air-transport statistics and prepares studies on aviation economics; fosters the development of air law conventions and provides technical assistance to states in developing civil aviation programmes.
Organization. The principal organs of ICAO are an Assembly, consisting of all members of the Organization, and a Council, which is composed of 36 states elected by the Assembly for three years, which meets in virtually continuous session. In electing these states, the Assembly must give adequate representation to: (1) states of major importance in air transport; (2) states which make the largest contribution to the provision of facilities for the international civil air navigation; and (3) those states not otherwise included whose election would ensure that all major geographical areas of the world were represented. The budget approved for 2012 was $\$ 93 \cdot 1 \mathrm{~m}$. CDN.

\section{Headquarters: 999 University St., Montreal, PQ, Canada $\mathrm{H} 3 \mathrm{C} 5 \mathrm{H} 7$. \\ Website: http://www.icao.int \\ President of the Council: Roberto Kobeh González (Mexico). Secretary-General: Raymond Benjamin (France).}

Publications. Annual Report of the Council; ICAO Journal (six yearly; quarterly in Russian); ICAO Training Manual; Aircraft Accident Digest; Procedures for Air Navigation Services.

\section{International Fund for Agricultural Development (IFAD)}

The idea for an International Fund for Agricultural Development arose at the 1974 World Food Conference. An agreement to establish IFAD entered into force on 30 Nov. 1977, and the agency began its operations the following month. IFAD is an international financial institution and a United Nations specialized agency dedicated to eradicating rural poverty in developing countries. It mobilizes resources from its 167 member countries to provide low-interest loans and grants to help middle and low-income member countries fight poverty in their poor rural communities. IFAD works with national partners to design and implement innovative initiatives that fit within national policies and systems. These enable poor rural people to access the assets, services, knowledge, skills and opportunities they need to overcome poverty. Since starting operations in 1978, IFAD has invested more than US $\$ 14.7 \mathrm{bn}$. in 924 projects and programmes that have reached over $400 \mathrm{~m}$. people.

Organization. The highest body is the Governing Council, on which all 169 member countries are represented. Operations are overseen by an 18-member Executive Board (with 18 alternate members), which is responsible to the Governing Council. The Fund works with many partner institutions, including the World Bank, regional development banks and financial agencies, and other UN agencies; many of these co-finance IFAD programmes and projects.

Headquarters: Via Paolo di Dono 44, 00142 Rome, Italy.

Website: http://www.ifad.org

President: Kanayo F. Nwanze (Nigeria).

Publications. Annual Report; Polishing the Stone; What Meets the Eye: Images of Rural Poverty.

\section{International Labour Organization (ILO)}

Origin. The ILO was established in 1919 under the Treaty of Versailles as an autonomous institution associated with the League of Nations. An agreement establishing its relationship with the UN was approved in 1946, making the ILO the first Specialized Agency to be associated with the UN. An intergovernmental agency with a tripartite structure, in which representatives of governments, employers and workers participate, it seeks through international action to improve labour and living conditions, to promote productive employment and social justice for working people everywhere. On its fiftieth 
anniversary in 1969 it was awarded the Nobel Peace Prize. In Feb. 2013 it numbered 185 members.

Functions. The ILO's programme and budget set out four strategic objectives for the Organization at the turn of the century: i) to promote and realize fundamental principles and rights at work; ii) to create greater opportunities for women and men to secure decent employment and income; iii) to enhance the coverage and effectiveness of social protection for all; iv) to strengthen tripartism and social dialogue. The International Labour Conference 2011 adopted a budget of US $\$ 861.6 \mathrm{~m}$. for the 2012-13 biennium.

One of the ILO's principal functions is the formulation of international standards in the form of International Labour Conventions and Recommendations. Member countries are required to submit Conventions to their competent national authorities with a view to ratification. If a country ratifies a Convention it agrees to bring its laws into line with its terms and to report periodically how these regulations are being applied. More than 7,500 ratifications of 189 Conventions had been deposited by 30 June 2012. Procedures are in place to ascertain whether Conventions thus ratified are effectively applied. Recommendations do not require ratification, but member states are obliged to consider them with a view to giving effect to their provisions by legislation or other action. By 30 June 2012 the International Labour Conference had adopted 202 Recommendations.

In June 1998 delegates to the 86th International Labour Conference adopted an ILO Declaration in Fundamental Principles and Rights at Work, committing the Organization's member states to respect the principles inherent in a number of core labour standards: the right of workers and employers to freedom of association and the effective right to collective bargaining, and to work toward the elimination of all forms of forced or compulsory labour, the effective abolition of child labour and the elimination of discrimination in respect of employment and occupation.

Activities. In addition to its research and advisory activities, the ILO now conducts more than 1,000 technical co-operation programmes in over 80 countries with the help of some 60 donor institutions worldwide. The ILO has decentralized most such activities to its regional, area and branch offices in over 40 countries. Decent Work Country Programmes have been established as the main vehicle for delivery of ILO support to countries.

The ILO's standard-setting and technical co-operation are reinforced by an extensive research, training, education and publications programme. It has established two specialized educational institutions: the International Institute for Labour Studies in Geneva, and the International Centre for Advanced Technical and Vocational Training in Turin.

The International Institute for Labour Studies promotes the study and discussion of policy issues. The core theme of its activities is the interaction between labour institutions, development and civil society in a global economy. It identifies emerging social and labour issues by opening up new areas for research and action; and encourages systematic dialogue on social policy between the tripartite constituency of the ILO and the international academic community, and other public opinionmakers.

The International Training Centre was set up in 1965 to lead the training programmes implemented by the ILO as part of its technical co-operation activities. Member states and the UN system also call on its resources and experience, and a UN Staff College was established on the Turin Campus in 1996.

In June 2009 the International Labour Conference unanimously adopted a 'Global Jobs Pact' to address the social and employment impact of the recent international financial and economic crisis. The Pact promotes a productive recovery centred on investments, employment and social protection. It provides an internationally agreed basis for policy-making designed to reduce the time lag between economic recovery and a recovery with decent work opportunities.

Organization. The International Labour Conference is the supreme deliberative organ of the ILO; it meets annually in Geneva. National delegations are composed of two government delegates, one employers' delegate and one workers' delegate. The Governing Body, elected by the Conference, is the Executive Council. It is composed of 28 government members, 14 workers' members and 14 employers' members. Ten governments of countries of industrial importance hold permanent seats on the Governing Body. These are: Brazil, China, Germany, France, India, Italy, Japan, Russia, UK and USA. The remaining 18 government members are elected every three years. Workers' and employers' representatives are elected as individuals, not as national candidates.

Headquarters: International Labour Office, 4 route des

Morillons, CH-1211 Geneva 22, Switzerland.

Website: http://www.ilo.org

Email: ilo@ilo.org

Director-General: Guy Ryder (United Kingdom).

Governing Body Chairman: Gilles de Robien (France).

Publications include: International Labour Review; Bulletin of Labour Statistics; Official Bulletin and Labour Education; Yearbook of Labour Statistics (annual); World of Work Report (annual); Global Employment Trends (annual); Encyclopaedia of Occupational Health and Safety; Key Indicators of the Labour Market (KILM).

\section{International Maritime Organization (IMO)}

Origin. The International Maritime Organization (formerly the InterGovernmental Maritime Consultative Organization) was established as a specialized agency of the UN by a convention drafted in 1948 at a UN maritime conference in Geneva. The Convention became effective on 17 March 1958 when it had been ratified by 21 countries, including seven with at least $1 \mathrm{~m}$. gross tons of shipping each. The IMCO started operations in 1959 and changed its name to the IMO in 1982.

Functions. To facilitate co-operation among governments on technical matters affecting merchant shipping, especially concerning safety and security at sea; to prevent and control marine pollution caused by ships; to facilitate international maritime traffic. The IMO is responsible for convening international maritime conferences and for drafting international maritime conventions. It also provides technical assistance to countries wishing to develop their maritime activities, and acts as a depositary authority for international conventions regulating maritime affairs. The World Maritime University (WMU), at Malmö, Sweden, was established in 1983; the IMO International Maritime Law Institute (IMLI), at Valletta, Malta and the IMO International Maritime Academy, at Trieste, Italy, both in 1989

Organization. The IMO has 170 members and three associate members. The Assembly, composed of all member states, normally meets every two years. The 40 -member Council acts as governing body between sessions. There are four principal committees (on maritime safety, legal matters, marine environment protection and technical co-operation), which submit reports or recommendations to the Assembly through the Council, and a Secretariat. The budget for 2010-11 amounted to $£ 61,151,200$.

Headquarters: 4 Albert Embankment, London SE1 7SR, UK.

Website: http://www.imo.org

Email: info@imo.org

Secretary-General: Koji Sekimizu (Japan).

Publication. IMO News. 


\section{International Monetary Fund (IMF)}

Established in 1945 as an independent organization, the International Monetary Fund began financial operations on 1 March 1947. An agreement of mutual co-operation with the UN came into force on 15 Nov. 1947. The first amendment to the Articles of Agreement, creating the special drawing right (SDR), the IMF's reserve asset, took effect on 28 July 1969. The second amendment took effect on 1 April 1978, and established a new code of conduct for exchange arrangements in the wake of the collapse of the par value system. The third amendment came into force on 11 Nov. 1992; it allows for the suspension of voting and related rights of any member that fails to settle its outstanding obligations to the IMF. The fourth Amendment, which came into force on 10 Aug. 2009, provides for a special one-time allocation of SDRs.

Members. Afghanistan, Albania, Algeria, Angola, Antigua and Barbuda, Argentina, Armenia, Australia, Austria, Azerbaijan, Bahamas, Bahrain, Bangladesh, Barbados, Belarus, Belgium, Belize, Benin, Bhutan, Bolivia, Bosnia and Herzegovina, Botswana, Brazil, Brunei, Bulgaria, Burkina Faso, Burundi, Cambodia, Cameroon, Canada, Cape Verde, Central African Republic, Chad, Chile, China, Colombia, Comoros, Democratic Republic of the Congo, Republic of the Congo, Costa Rica, Côte d'Ivoire, Croatia, Cyprus, Czech Republic, Denmark, Djibouti, Dominica, Dominican Republic, Ecuador, Egypt, El Salvador, Equatorial Guinea, Eritrea, Estonia, Ethiopia, Fiji Islands, Finland, France, Gabon, Gambia, Georgia, Germany, Ghana, Greece, Grenada, Guatemala, Guinea, Guinea-Bissau, Guyana, Haiti, Honduras, Hungary, Iceland, India, Indonesia, Iran, Iraq, Ireland, Israel, Italy, Jamaica, Japan, Jordan, Kazakhstan, Kenya, Kiribati, South Korea, Kosovo, Kuwait, Kyrgyzstan, Laos, Latvia, Lebanon, Lesotho, Liberia, Libya, Lithuania, Luxembourg, Macedonia, Madagascar, Malawii, Malaysia, Maldives, Mali, Malta, Marshall Islands, Mauritania, Mauritius, Mexico, Micronesia, Moldova, Mongolia, Montenegro, Morocco, Mozambique, Myanmar, Namibia, Nepal, Netherlands, New Zealand, Nicaragua, Niger, Nigeria, Norway, Oman, Pakistan, Palau, Panama, Papua New Guinea, Paraguay, Peru, Philippines, Poland, Portugal, Qatar, Romania, Russia, Rwanda, St Kitts and Nevis, St Lucia, St Vincent and the Grenadines, Samoa, San Marino, São Tomé e Príncipe, Saudi Arabia, Senegal, Serbia, Seychelles, Sierra Leone, Singapore, Slovakia, Slovenia, Solomon Islands, Somalia, South Africa, South Sudan, Spain, Sri Lanka, Sudan, Suriname, Swaziland, Sweden, Switzerland, Syria, Tajikistan, Tanzania, Thailand, Timor-Leste, Togo, Tonga, Trinidad and Tobago, Tunisia, Turkey, Turkmenistan, Tuvalu, Uganda, Ukraine, United Arab Emirates, UK, USA, Uruguay, Uzbekistan, Vanuatu, Venezuela, Vietnam, Yemen, Zambia, Zimbabwe.

Aims. To promote international monetary co-operation, the expansion of international trade and exchange rate stability; to assist in the removal of exchange restrictions and the establishment of a multilateral system of payments; and to alleviate any serious disequilibrium in members' international balance of payments by making the financial resources of the IMF available to them, usually subject to economic policy conditions.

Activities. The IMF is mandated to oversee the international monetary system and monitor the economic and financial policies of its member countries. The IMF highlights possible risks to domestic and external stability and advises on policy adjustments.

Lending. A core responsibility of the IMF is to provide loans to member countries experiencing balance of payments problems. This financial assistance enables countries to rebuild their international reserves, stabilize their currencies, continue paying for imports and restore conditions for strong economic growth, while undertaking policies to correct underlying problems. Unlike development banks, the IMF does not lend for specific projects.

The IMF has various loan instruments, or 'facilities', that are tailored to address the specific circumstances of its diverse membership. Nonconcessional loans are provided mainly through Stand-By Arrangements (SBAs) and the Extended Fund Facility (which is useful primarily for longer-term needs). The Flexible Credit Line (FCL) was introduced in 2009, for countries with very strong fundamentals, policies and track records of policy implementation.

The IMF also offers special financing facilities for low-income countries. A new Poverty Reduction and Growth Trust, effective from Jan. 2010, incorporates: the Extended Credit Facility, which provides flexible medium-term support; the Standby Credit Facility, which addresses short-term and precautionary needs; and the Rapid Credit Facility, which offers emergency support with limited conditionality. The IMF also provides emergency assistance to support recovery from natural disasters and conflicts, in some cases at concessional interest rates.

A major reform of the IMF's lending facilities took place in March 2009. Conditions linked to IMF loan disbursements are to be better focused and more adequately tailored to the varying strengths of countries' policies and fundamentals. The flexibility of the SBA has been enhanced. In addition, access limits have been doubled, the cost and maturity structure of the Fund's lending has been simplified and its lending facilities have been streamlined.

Technical assistance. The IMF provides technical assistance in its areas of core expertise: macroeconomic policy, tax policy and revenue administration, expenditure management, monetary policy, the exchange rate system, financial sector sustainability, and macroeconomic and financial statistics. About $90 \%$ of IMF technical assistance goes to low and lower-middle income countries. The IMF operates eight regional technical assistance centres: in the Pacific (Fiji Islands), the Caribbean (Barbados), four in Africa (Gabon, Mali, Mauritius and Tanzania), the Middle East (Lebanon) and Central America (Guatemala).

Finances. Quota subscriptions from member countries are the IMF's main source of financing. A member's quota is largely determined by its economic position relative to other members; it is also linked to their drawing rights on the IMF, their voting power and their share of SDR allocations. Quotas are reviewed at least every five years, with the most recent review completed in Dec. 2010. The IMF can supplement its resources through borrowing if it believes that resources might fall short of members' needs.

The General Arrangements to Borrow (GAB) and New Arrangements to Borrow (NAB) are credit arrangements between the IMF and a group of member countries and institutions to provide supplementary resources to the IMF to deal with an exceptional situation that poses a threat to the stability of that system. The GAB, established in 1962, enables the IMF to borrow specified amounts of currencies from 11 industrial countries (or their central banks) under certain circumstances, at marketrelated rates of interest. The potential credit available to the IMF under the GAB totals SDR 17bn., with an additional SDR 1.5bn. available under an associated arrangement with Saudi Arabia. The NAB, which came into effect in 1998, is a set of credit arrangements between the IMF and 26 member countries and institutions. Importantly, the $\mathrm{NAB}$ is the facility of first and principal recourse vis-à-vis the GAB. The maximum amount of resources available to the IMF under the NAB and GAB is SDR $34 \mathrm{bn}$.

In April 2009 the G20 agreed to increase the lending resources available to the IMF by up to US $\$ 500 \mathrm{bn}$., thereby tripling total 
pre-crisis lending resources. The increase was to be made through immediate bilateral financing from IMF member countries and by subsequently incorporating this financing into an expanded and more flexible NAB increased by up to US $\$ 500 \mathrm{bn}$. This objective was achieved by Sept. 2009.

Bilateral loans. Under such an agreement, the member normally commits to allow the Fund to make drawings up to a specified ceiling during the period for which drawings can be made. In 2009 the IMF signed a number of bilateral loan agreements.

IMF notes. Some official creditors may prefer to invest in paper or notes issued by the IMF. In 2009 the IMF's Executive Board approved a new framework for issuing notes to the official sector. China was the first country to have signed such a note purchase agreement.

SDR allocations. The IMF may allocate SDRs to members in proportion to their IMF quotas. Such an allocation provides each member with a costless asset. There have been three general SDR allocations, made in response to a long-term global need for reserve assets: (i) SDR 9.3bn., distributed in 1970-72; (ii) SDR 12.3bn., distributed in 1979-81; and (iii) SDR 162.1bn., distributed in Aug. 2009. A special one-off allocation of SDRs amounting to SDR 21.4bn. was implemented on 9 Sept. 2009. This allocation was for those countries that joined the Fund after 1981-more than one fifth of the IMF membership-and had never received an SDR allocation.

Governance reform. Implemented on 28 April 2008 this reform aims to make quotas more responsive to economic realities by increasing the representation of fast-growing economies while at the same time giving low-income countries more say in the IMF's decision making. The reform builds on an initial step agreed by the IMF's membership in Sept. 2006 to have ad hoc quota increases for four countries-China, South Korea, Mexico and Turkey. In Dec. 2010 the IMF Board of Governors approved a shift in quota share to dynamic emerging markets and developing countries of more than $6 \%$ using the current quota formula as the basis. However, the IMF membership failed to approve the reform at its annual meeting in Oct. 2012 and agreement on a revised quota formula has still to be reached.

Organization. The highest authority is the Board of Governors; each member government is represented. The Board of Governors has delegated many of its powers to the 24 executive directors in Washington, D.C., who are appointed or elected by individual member countries or groups of countries. The managing director is selected by the executive directors and serves as chairman of the Executive Board, but may not vote except in case of a tie. The term of office is for five years, but may be extended or terminated at the discretion of the executive directors. The managing director is responsible for the ordinary business of the IMF, under the direction of the executive directors, and supervises a staff of about 2,400. There are three deputy managing directors. As of Feb. 2013 the IMF had 188 members.

The IMF Institute is a specialized department providing training in macroeconomic analysis and policy, and related subjects, for officials of member countries. In addition to training offered in Washington, D.C., the IMF also offers training for country officials through a network of seven regional training institutes and programmes. These are: the IMF-Singapore Regional Training Institute; the Joint Africa Institute (in Tunisia); the Joint China-IMF Training Program (in Dalian, China); the Joint IMF-Arab Monetary Fund Regional Training Program (in the United Arab Emirates); the Joint India-IMF Training Program (in Pune, India); the Joint Regional Training Center for Latin America (in Brazil); and the Joint Vienna Institute (in Austria).

\section{Current Leaders}

\section{Christine Lagarde}

\section{Position}

Managing Director

\section{Introduction}

Christine Lagarde became managing director of the IMF in July 2011, against a backdrop of global financial instability and uncertainty. The 11th consecutive European to head the Fund, she promised to give more voting power to developing nations. One of her key challenges has been formulating the IMF response to the continuing sovereign debt crises.

\section{Early Life}

Born on 1 Jan. 1956 in Paris, Christine Lagarde attended school in Le Havre, France and Holton-Arms School in Bethesda, Maryland, USA before studying law at the Université de Paris $\mathrm{X}$-Nanterre. After obtaining a masters degree from the Institut d'études politiques d'Aix-en-Provence, in 1981 she joined the Paris office of international law firm Baker \& McKenzie, specializing in anti-trust law, employment law, and acquisitions and mergers.

Made a partner in 1987, she served on the executive committee from 1995-2004, moving to Chicago in 1999 when she became chairman of the global executive committee. As a member of a Washington-based think tank, the Centre for Strategic and International Studies, Lagarde headed the US-Poland defence industries working group from 1995-2002, promoting the interests of US and Polish companies.

She returned to France in 2005 to serve as minister for foreign trade in Dominique de Villepin's government, overseeing the growth of exports. She was minister of agriculture and fisheries from May-June 2007, before being appointed finance minister by President Sarkozy. With the onset of the global economic crisis in 2008 she gained a reputation as an astute negotiator, winning praise domestically for her representation of French interests on the international stage. In 2010 she was closely involved in the negotiations over IMF bailout loans for eurozone countries.

IMF managing director Dominique Strauss-Kahn resigned in May 2011, accused of sexual assault, and Lagarde emerged as the favourite to replace him, ahead of Agustín Carstens of Mexico. She was backed by the USA and, despite widely expressed concern over continued European dominance of the Fund, she also won support from the BRIC nations of Brazil, Russia, India and China.

\section{Career in Office}

Lagarde took office on 5 July 2011, promising to implement reforms to IMF governance, including more voting power for emerging nations. Her main preoccupation to date, however, has been the containment of sovereign debt crises in economically advanced countries around the world, and particularly in the eurozone where the IMF has contributed financial support for Greece, Ireland and Portugal in an international effort to sustain the viability of the European single currency. She has called for the eurozone to move swiftly towards a fiscal union.

Headquarters: 700 19th St., NW, Washington, D.C., 20431, USA; 1900 Pennsylvania Ave., NW, Washington, D.C., 20431, USA. European office in Paris and regional offices in Tokyo and Warsaw.

Website: http://www.imf.org/external/index.htm

Email: publicaffairs@imf.org

Managing Director: Christine Lagarde (France).

Publications: Annual Report of the Executive Board; Annual Report on Exchange Arrangements and Exchange Restrictions; International Financial Statistics (monthly); IMF Survey (online); IMF Economic Review; World Economic Outlook; Global Financial Stability Report; and Finance \& Development. More publications information may be found online at: http://www.imf.org/external/pubind.htm. 


\section{Further Reading}

Copelovitch, Mark S., The International Monetary Fund in the Global Economy: Banks, Bonds, and Bailouts. 2010

Dhingra, Vasudha, The International Monetary Fund and the World Bank: Aspects of Convergence and Divergence. 2010

Humphreys, N. K., Historical Dictionary of the International Monetary Fund. 1994

James, H., International Monetary Cooperation since Bretton Woods. 1996

Samans, Richard, Uzan, Marc and Lopez-Claros, Augusto, The International Monetary System, the IMF, and the G-20: A Great Transformation in the Making? 2007

Woods, N., The Globalizers: The IMF, the World Bank and Their Borrowers. 2007

\section{International Telecommunication Union (ITU)}

Origin. Founded in Paris in 1865 as the International Telegraph Union, the International Telecommunication Union took its present name in 1934 and became a specialized agency of the United Nations in 1947. Therefore, the ITU is the world's oldest intergovernmental body.

Functions. To maintain and extend international co-operation for the improvement and rational use of telecommunications of all kinds, and promote and offer technical assistance to developing countries in the field of telecommunications; to promote the development of technical facilities and their most efficient operation to improve the efficiency of telecommunication services, increasing their usefulness and making them, so far as possible, generally available to the public; to harmonize the actions of nations in the attainment of these ends.

Organization. The supreme organ of the ITU is the Plenipotentiary Conference, which normally meets every four years. A 48-member Council, elected by the Conference, meets annually in Geneva and is responsible for ensuring the co-ordination of the four permanent organs at ITU headquarters: the General Secretariat; Radiocommunication Sector; Telecommunication Standardization Sector; and Telecommunication Development Sector. The Secretary-General is also elected by the Conference. ITU has 193 member countries; a further 700 scientific and technical companies, public and private operators, broadcasters and other organizations are also ITU members.

Headquarters: Place des Nations, CH-1211 Geneva 20, Switzerland.

Website: http://www.itu.int

Secretary-General: Hamadoun Touré (Mali).

\section{United Nations Educational, Scientific and Cultural Organization (UNESCO)}

Origin. UNESCO's Constitution was signed in London on 16 Nov. 1945 by 37 countries and the Organization came into being in Nov. 1946 on the premise that: 'Since wars begin in the minds of men, it is in the minds of men that the defences of peace must be constructed'. In Feb. 2013 UNESCO had 195 members including the UK, which rejoined in 1997 having left in 1985, and the USA, which rejoined in 2003 having left in 1984. There are also eight associate members that are not members of the UN (Aruba, British Virgin Islands, Cayman Islands, Curaçao, the Faroe Islands, Macao, Sint Maarten and Tokelau).

Aims and Activities. UNESCO's primary objective is to contribute to peace and security in the world by promoting collaboration among the nations through education, science, communication, culture and the social and human sciences in order to further universal respect for justice, democracy, the rule of the law, human rights and fundamental freedoms, affirmed for all peoples by the UN Charter. Africa and gender equality are the Organization's two chief global priorities.
Education. Various activities support and foster national projects to renovate education systems and develop alternative educational strategies towards a goal of lifelong education for all. The World Development Forum in Dakar in 2000 set an agenda for progress towards this aim expressed as six goals. Two of these, attaining universal primary education by 2015 and gender parity in schooling by 2005 , were also UN Millennium Development Goals. Three elements define the context for pursuing this purpose: promoting education as a fundamental right, improving the quality of education and stimulating experimentation, innovation and policy dialogue.

Science. UNESCO seeks to promote international scientific co-operation and encourages scientific research designed to improve living conditions and to protect ecosystems. Several international programmes to better understand the Earth's resources towards the advancement of sustainable development have been initiated, including the Man and the Biosphere (MAB) programme, the International Hydrological Programme (IHP), the Intergovernmental Oceanographic Commission (IOC) and the International Geoscience Programme (IGCP).

Culture. Promoting the preservation of heritage, both tangible and intangible, cultural diversity and intercultural dialogue is the principal priority of UNESCO's cultural programmes. UNESCO's World Heritage List, now covering 962 sites around the world, promotes the preservation of monuments, cultural landscapes and natural sites.

Communication. Activities are geared to promoting the free flow of information, freedom of expression, press freedom, media independence and pluralism. Another priority is to promote multilingualism on the internet, bridge the digital divide and help disadvantaged groups in North and South participate in the knowledge societies created through the information and communication technologies. To this end, UNESCO promotes access to public domain information, as well as encouraging the creation of local content.

Social and Human Sciences. UNESCO works to advance knowledge and intellectual co-operation in order to facilitate social transformations conducive to justice, freedom, peace and human dignity. It seeks to identify evolving social trends and develops and promotes principles and standards based on universal values and ethics, such as the Universal Declaration on the Human Genome and Human Rights (1997) and the International Declaration on Human Genetic Data (2003).

Organization. The General Conference, composed of representatives from each member state, meets biennially to decide policy, programme and budget. A 58-member Executive Board elected by the Conference meets twice a year and there is a Secretariat. In addition, national commissions act as liaison groups between UNESCO and the educational, scientific and cultural life of their own countries. The regular budget for the biennium $2012-13$ is US $\$ 465 \mathrm{~m}$., with significant extra-budgetary contributions for specific programmes provided by both public and private bodies.

There are also ten separate UNESCO institutes and centres: the International Bureau of Education (IBE), in Geneva; the UNESCO Institute for Lifelong Learning (UIL), in Hamburg; the International Institute for Educational Planning (IIEP), in Paris and Buenos Aires; the International Institute for Capacity Building in Africa (IICBA), in Addis Ababa; the International Institute for Higher Education in Latin America and the Caribbean (IESALC), in Caracas; the Institute for Information Technologies in Education (IITE), in Moscow; the UNESCO Institute for Statistics (UIS), in Montreal; the UNESCO International Centre for Technical and Vocational Education and Training (UNEVOC), in Bonn; the UNESCO-IHE Institute for 
Water Education (UNESCO-IHE), in Delft; and the International Centre for Theoretical Physics (ICTP), in Trieste.

Headquarters: UNESCO House, 7 Place de Fontenoy, 75352 Paris 07 SP, France; 1 rue Miollis, 75732 Paris Cedex 15,

France.

Website: http://www.unesco.org

Director-General: Irina Bokova (Bulgaria).

Periodicals (published quarterly). Museum International; International Social Science Journal; The UNESCO Courier; Prospects; Copyright Bulletin; World Heritage Review.

\section{United Nations Industrial Development Organization (UNIDO)}

Origin. UNIDO was established by the UN General Assembly in 1966 and became a UN specialized agency in 1985.

Aims and Activities. UNIDO helps developing countries in the formulation of policies and programmes in the field of industrial development; analyses trends, disseminates information and co-ordinates activities in their industrial development; acts as a forum for consultations and negotiations directed towards the industrialization of developing countries; and provides technical co-operation to developing countries for the implementation of their development plans for sustainable industrialization in their public and private sectors.

UNIDO focuses its efforts on three thematic priority areas: poverty reduction through productive activities; trade capacitybuilding; and energy and the environment. Activities under the thematic priorities are reflected in UNIDO's medium-term programme frameworks and biennial programme documents. They are strictly aligned with the priorities of the current UN Decade for the Eradication of Poverty and relevant multilateral declarations.

Organization. As part of the United Nations common system, UNIDO has the responsibility for promoting industrialization throughout the developing world, in co-operation with its 174 member states. Its headquarters are in Vienna, Austria. In 2010 UNIDO's field network included ten regional offices, 19 country offices, 18 desks, five focal points and one regional centre, thus offering a UNIDO field presence in 53 countries. In addition to this official field structure there are a number of project-funded field units with UNIDO staff, including 13 Investment and Technology Promotion Offices, 43 National Cleaner Production Centres, 14 International Technology Centres, 32 Sub-contracting and Partnership Exchanges and two South-South Cooperation Centres.

The General Conference meets every two years to determine policy and approve the budget. The 53-member Industrial Development Board (membership according to constitutional lists) is elected by the General Conference. The General Conference also elects a 27-member Programme and Budget Committee for two years and appoints a Director-General for four years.

Finance. UNIDO's financial resources come from the regular and operational budgets, as well as voluntary contributions, budgeted for $2012-13$ at US $\$ 153.2 \mathrm{~m}$., US $\$ 28.8 \mathrm{~m}$. and US $\$ 273.1 \mathrm{~m}$. respectively, totalling US $\$ 455 \cdot 2 \mathrm{~m}$. The regular budget derives mainly from assessed contributions from member states with a marginal proportion provided from such other sources as interest income, sales publications and government contributions to the UNIDO field offices.

The Constitution of UNIDO provides for $6 \%$ of the net regular budget to be used for the Regular Programme of Technical Cooperation. These resources are primarily used for supporting the Organization's operational and normative activities. The operational budget derives mainly from support cost income (of $5-13 \%$ ) earned from the implementation of technical cooperation activities. Technical co-operation is funded mainly from voluntary contributions from donor countries and institutions as well as UNDP, the Multilateral Fund for the Implementation of the Montreal Protocol, the Global Environment Facility and the Common Fund for Communities.

Headquarters: Vienna International Centre, Wagramerstr. 5, POB 300, A-1400 Vienna, Austria.

Website: http://www.unido.org

Director-General: Kandeh Yumkella (Sierra Leone).

Publications. UNIDOScope (weekly internet newspaper); UNIDO Annual Report; Industry for Growth into the New Millennium, African Industry 2000: The Challenge of Going Global; Using Statistics for Process Control and Improvement: An Introduction to Basic Concepts and Techniques; Guidelines for Project Evaluation; Practical Appraisal for Industrial Project Applications-Application of Social Cost-Benefit Analysis in Pakistan; Making It (quarterly); Manual for the Evaluation of Industrial Projects; Guide to Practical Project Appraisal-Social Benefit-Cost Analysis in Developing Countries; Manual for Small Industrial Businesses: Project Design and Appraisal; Manual for the Preparation of Industrial Feasibility Studies; Manual on Technology Transfer Negotiations; Guidelines for Infrastructure Development Through Build-Operate-Transfer (BOT) Projects; Gearing up for a New Development Agenda; Reforming the UN System: UNIDO's Need-Driven Model; UNIDO Times (newsletter); World Directory of Industrial Information Sources; Woodworking Machinery: A Manual on Selection Options; Competition and the World Economy; The International Yearbook of Industrial Statistics 2013; Industrial Development Report 2011.

\section{Universal Postal Union (UPU)}

Origin. The UPU was established in 1875, when the Universal Postal Convention adopted by the Postal Congress of Berne on 9 Oct. 1874 came into force. It has 192 member countries.

Functions. The UPU provides co-operation between postal services and helps to ensure a universal network of up-to-date products and services. To this end, UPU members are united in a single postal territory for the reciprocal exchange of correspondence. A Specialized Agency of the UN since 1948, the UPU is governed by its Constitution, adopted in 1964 (Vienna), and subsequent protocol amendments (1969, Tokyo; 1974, Lausanne; 1984, Hamburg; 1989, Washington; 1994, Seoul; 1999, Beijing; 2004, Bucharest; 2008, Geneva).

Organization. It is composed of a Universal Postal Congress which meets every four years; a 41-member Council of Administration, which meets annually and is responsible for supervising the affairs of the UPU between Congresses; a 40member Postal Operations Council; and an International Bureau which functions as the permanent secretariat, responsible for strategic planning and programme budgeting. A new UPU body, the Consultative Committee, was created at the Bucharest Congress. This committee represents the external shareholders of the postal sector as well as UPU member countries. The budget for 2011 was $37 \cdot 2 \mathrm{~m}$. Swiss francs.

Headquarters: Weltpoststrasse 4, 3000 Berne 15, Switzerland.

Website: http://www.upu.int

Director-General: Bishar Abdirahman Hussein (Kenya).

Publications. Annual Report; ICTs, new services and transformation of the Post (2010); Postal Economics in Developing Countries: Posts, Infrastructure of the 21st Century? (2009); Postal Statistics (annual); Union Postale (quarterly); POST ${ }^{*}$ Code (also in CD-ROM); Bucharest World Postal Strategy (2004)

\section{World Health Organization (WHO)}

Origin. An International Conference convened by the UN Economic and Social Council to consider a single health 
organization resulted in the adoption on 22 July 1946 of the Constitution of the World Health Organization, which came into force on 7 April 1948.

Functions. WHO's objective, as stated in the first article of the Constitution, is 'the attainment by all peoples of the highest possible level of health'. As the directing and co-ordinating authority on international health, it establishes and maintains collaboration with the UN, specialized agencies, governments, health administrations, professional and other groups concerned with health. The Constitution also directs WHO to assist governments to strengthen their health services; to stimulate and advance work to eradicate diseases; to promote maternal and child health, mental health, medical research and the prevention of accidents; to improve standards of teaching and training in the health professions, and of nutrition, housing, sanitation, working conditions and other aspects of environmental health. The Organization is also empowered to propose conventions, agreements and regulations, and make recommendations about international health matters; to develop, establish and promote international standards concerning foods, biological, pharmaceutical and similar substances; to revise the international nomenclature of diseases, causes of death and public health practices.

Methods of work. Co-operation in country projects is undertaken only on the request of the government concerned, through the six regional offices of the Organization. Worldwide technical services are made available by headquarters. Expert committees, chosen from the 47 advisory panels of experts, meet to advise the Director-General on a given subject. Scientific groups and consultative meetings are called for similar purposes. To further the education of health personnel of all categories, seminars, technical conferences and training courses are organized, and advisors, consultants and lecturers are provided. WHO awards fellowships for study to nationals of member countries.

Activities. The main thrust of WHO's activities in recent years has been towards promoting national, regional and global strategies for the attainment of the main social target of the member states: 'Health for All in the 21st Century', or the attainment by all citizens of the world of a level of health that will permit them to lead a socially and economically productive life. Almost all countries indicated a high level of political commitment to this goal; and guiding principles for formulating corresponding strategies and plans of action were subsequently prepared.

WHO has organized its responsibilities into four priorities: enhancing global health security, which includes preventing, detecting and containing disease outbreaks, preparing the world for controlling pandemic influenza, combating new diseases such as SARS, preparing for emergencies and responding quickly to minimize death and suffering; accelerating progress on the Millennium Development Goals (MDGs) by reducing maternal and child mortality, tackling the global epidemics of HIV/AIDS, tuberculosis and malaria, promoting safe drinking water and sanitation, promoting gender equality and increasing access to essential medicines; responding to non-communicable disease such as cardiovascular diseases, diabetes and cancers by reducing smoking, promoting a healthy diet and physical activity and reducing violence and road traffic crashes; promoting equity in health through strengthening health systems to reach everyone, particularly the most vulnerable people.

World Health Day is observed on 7 April every year. The 2013 theme for World Health Day was 'High blood pressure'; the theme for 2012 was 'Ageing and health'. World No-Tobacco Day is held on 31 May each year; International Day Against Drug Abuse on 26 June; World AIDS Day on 1 Dec.

The 50th World Health Assembly which met in 1997 adopted numerous resolutions on public health issues. The World Health Report, 1997: Conquering suffering, enriching humanity focused on 'non-communicable diseases'. It warned that the human and social costs of cancer, heart disease and other chronic diseases will rise unless confronted now.

The number of cancer cases is expected to increase by $37 \%$ between 2007 and 2030. The incidence of lung cancers in women and prostate cancers in men in the Western world is becoming far more prevalent. The incidence of other cancers is also rising rapidly, especially in developing countries. Heart disease and stroke, the leading causes of death in richer nations, will become more common in poorer countries. The number of people affected by diabetes has risen from $135 \mathrm{~m}$. in 1997 to $220 \mathrm{~m}$. in 2009 , and is forecast to increase to over $360 \mathrm{~m}$. by 2030 . There is likely to be a huge rise in some mental and neurological disorders, especially dementias and particularly Alzheimer's disease, which is projected to affect $34 \mathrm{~m}$. people by 2025 . In 2003 an estimated $450 \mathrm{~m}$. people suffered from mental and neurological disorders. Dementia affected an estimated $24 \mathrm{~m}$. people in 2007 and some $50 \mathrm{~m}$. worldwide suffered from epilepsy.

These projected increases are reported to be owing to a combination of factors, not least population ageing and the rising prevalence of unhealthy lifestyles. Average life expectancy at birth globally reached 68 years in 2008. It is now well over 70 years in many countries and exceeds 80 years in some. In 2010 there were an estimated $524 \mathrm{~m}$. people over 65 . By 2030 that number is expected to rise to $976 \mathrm{~m}$., representing nearly $12 \%$ of the world's population.

According to $\mathrm{WHO}$, the top ten causes of death in the world in 2008 were: coronary heart disease, $7 \cdot 3 \mathrm{~m}$. deaths; stroke and other cerebrovascular disease, $6.2 \mathrm{~m}$.; lower respiratory infections, $3.5 \mathrm{~m}$; chronic obstructive pulmonary disease, $3.3 \mathrm{~m}$.; diarrhoeal diseases, $2.5 \mathrm{~m}$.; HIV/AIDS, $1.8 \mathrm{~m}$.; trachea, bronchus and lung cancers $1.4 \mathrm{~m}$.; tuberculosis, $1.3 \mathrm{~m}$.; diabetes mellitus, $1.3 \mathrm{~m}$.; road traffic accidents $1.2 \mathrm{~m}$. In total, tobacco use is responsible for the death of almost one in ten adults worldwide.

In response, WHO has called for an intensified and sustained global campaign to encourage healthy lifestyles and attack the main risk factors responsible for many of these diseases: unhealthy diet, inadequate physical activity, smoking and obesity.

The WHO Framework Convention on Tobacco Control (WHO FCTC) was developed in response to the globalization of the tobacco epidemic, and is the first global health treaty negotiated under the auspices of the World Health Organization. The provisions in the Treaty require countries to ban tobacco advertising, sponsorship and promotion; establish new packaging and labelling of tobacco products with prominent health warnings; establish smoking bans in public places, increase price and tax on tobacco products; and strengthen legislation to clamp down on tobacco smuggling, among other measures.

World Health Report, 2010: Health Systems Financing - The Path to Universal Coverage assesses the way health care is financed and what countries can do to modify their financing systems to ensure that all people can use health services, while being protected against financial hardship associated with paying for them. The report proposes ways the international community can better support efforts in low income countries to achieve universal coverage. Emphasis is placed on improving efficiency and moving away from direct payments towards prepayment and pooling.

Organization. The principal organs of WHO are the World Health Assembly, the Executive Board and the Secretariat. Each of the 194 member states has the right to be represented at the Assembly, which meets annually in Geneva. The 34-member Executive Board is composed of technically qualified health experts designated by as many member states as elected by the Assembly. The Secretariat consists of technical and administrative staff headed by a Director-General, who is appointed for not more than two five-year terms. Health activities in member countries are carried out through regional organizations which have been 
established in Africa (Brazzaville), South-East Asia (New Delhi), Europe (Copenhagen), Eastern Mediterranean (Cairo) and Western Pacific (Manila). The Pan American Sanitary Bureau in Washington serves as the regional office of WHO for the Americas. It is the oldest international health agency in the world and is the secretariat of the Pan American Health Organization (PAHO). Co-operation in country projects is undertaken only at the request of the government concerned, through the six regional offices.

Finance. The total two-year budget planned for 2010-11 was US\$5.4bn.

\section{Current Leaders}

\section{Margaret Chan Fung Fu-chun}

Position

Director-General

\section{Introduction}

Dr Margaret Chan was appointed Director-General of WHO on 9 Nov. 2006 to secure a scheduled five-year term from 4 Jan. 2007 to 30 June 2012. In May 2012 she was reappointed for a second term until the end of June 2017.

\section{Early Life}

Chan was born in 1947 in Hong Kong. She graduated in medicine from the University of Western Ontario, Canada in 1977, and joined the Hong Kong department of health as a medical officer in Dec. 1978. In 1985 she gained an MSc. in public health from the National University of Singapore. In June 1994 she became the health department's first female director. Her nine-year tenure was marked by outbreaks of H5N1 avian influenza in 1997 and SARS in 2003.

In 2003 Chan joined WHO as director of the department for protection of the human environment. She was promoted to director of communicable diseases surveillance and response in June 2005 and also became the representative of the directorgeneral for pandemic influenza. In Sept. that year she was appointed assistant director-general for communicable diseases. When Dr Lee Jong-wook died in May 2006, Chan was nominated by China to succeed him as Director-General.

\section{Career in Office}

Chan identified improvements in health of women and in Africa as key to her term. However, she courted early controversy when, in Feb. 2007, she was accused of favouring pharmaceutical companies over the sick in developing countries by humanitarian groups lobbying for cheaper generic drugs. Then in April she was criticized for her defence of WHO's refusal to extend membership to Taiwan. In June 2007 new international health regulations obliged governments to report potential pandemics to Chan as WHO Director-General immediately. In June 2009 WHO declared a global swine flu pandemic. The outbreak, first detected in March, had seemingly peaked in many countries by the end of the year, but Chan warned against complacency in tracking the evolution of the virus.

In Jan. 2011 Chan warned that WHO was overextended and facing serious funding shortfalls, necessitating administrative, budgetary and programmatic reform. She said that the organization needed to redirect resources in a more targeted manner, avoiding wasteful duplication with other health financiers and concentrating on areas where it could make the most impact.

Headquarters: 20 avenue Appia, CH-1211 Geneva 27,

Switzerland.

Website: http://www.who.int

Director-General: Dr Margaret Chan Fung Fu-chun (China).

Publications. Annual Report on World Health; Bulletin of WHO (6 issues a year); International Digest of Health Legislation (quarterly); Health and
Safety Guides; International Statistical Classification of Diseases and Related Health Problems; WHO Technical Report Series; WHO AIDS Series; Public Health Papers; World Health Statistics Annual; Weekly Epidemiological Record; WHO Drug Information (quarterly).

\section{World Intellectual Property Organization (WIPO)}

Origin. The World Intellectual Property Organization (WIPO) was established in 1967 following the conclusion of the Convention Establishing the World Intellectual Property Organization in Stockholm in 1967. It was given a mandate by its member states to promote the protection of intellectual property (IP) through co-operation among states and in collaboration with other international organizations. The WIPO Convention entered into force on 26 April 1970 and WIPO became a specialized agency of the United Nations in 1974

Aims and Activities. WIPO administers 24 treaties that deal with different legal and administrative aspects of intellectual property, notably the Paris Convention for the Protection of Industrial Property, the Patent Cooperation Treaty and the Bern Convention for the Protection of Literary and Artistic Works. WIPO is dedicated to developing a balanced and accessible international intellectual property (IP) system that rewards creativity, stimulates innovation and contributes to economic development while safeguarding the public interest.

In Dec. 2008 WIPO member states adopted a new strategic framework for the Organization comprising nine strategic goals that are designed to enable WIPO to more effectively respond to an evolving technological, cultural and geo-economic environment. In addition to goals relating to the balanced evolution of the international normative framework of IP, to facilitating the use of IP for development and to the provision of premier global IP services, WIPO's new goals include a focus on building respect for IP; on developing global IP infrastructure; on responsive communication; on becoming a world reference source for IP information; and on addressing IP in relation to global policy challenges such as climate change, public health and food security.

WIPO's activities fall broadly into three clusters of activities, namely: the progressive development of international IP law; IP capacity-building programmes to support the efficient use of IP, particularly in developing countries; and services to industry that facilitate the process of obtaining IP rights in multiple countries. Also, alternative dispute resolution options for private parties are available through the WIPO Arbitration and Mediation Center. The Center provides services under the Uniform Domain Name Dispute Resolution Policy (UDRP) designed to discourage and resolve the abusive registration of trademarks as domain names. WIPO also facilitates access to a number of IP-related databases and search services, including PATENSCOPE-a valuable technical resource that provides access to information about new technologies that are often disclosed for the first time as international patent applications.

Organization. As at Feb. 2013 WIPO had 185 member states. WIPO is unique among the family of UN organizations in that it is largely self-financing. The budget for the 2010-11 biennium was $618 \mathrm{~m}$. Swiss francs. Over $90 \%$ of the Organization's budget comes from earnings derived from the services that WIPO provides to industry and the private sector. The remainder of the budget is made up mainly of revenue generated by WIPO's Arbitration and Mediation Center, the sale of publications and contributions from member states.

Official languages: Arabic, Chinese, English, French, Russian and Spanish.

Headquarters: 34 chemin des Colombettes, $\mathrm{CH}-1211$

Geneva 20, Switzerland.

Website: http://www.wipo.int

Director-General: Francis Gurry (Australia). 
Periodicals. Industrial Property and Copyright (monthly, bi-monthly, in Spanish); PCT Gazette (weekly); PCT Newsletter (monthly); International Designs Bulletin (monthly); WIPO Gazette of International Marks (fortnightly); Intellectual Property in Asia and the Pacific (quarterly).

\section{World Meteorological Organization (WMO)}

Origin. A 1947 (Washington) Conference of Directors of the International Meteorological Organization (est. 1873) adopted a Convention creating the World Meteorological Organization. The WMO Convention became effective on 23 March 1950 and WMO was formally established. It was recognized as a Specialized Agency of the UN in 1951.

Functions. (1) To facilitate worldwide co-operation in the establishment of networks of stations for the making of meteorological observations as well as hydrological or other geophysical observations related to meteorology, and to promote the establishment and maintenance of meteorological centres charged with the provision of meteorological and related services; (2) to promote the establishment and maintenance of systems for the rapid exchange of meteorological and related information; (3) to promote standardization of meteorological and related observations and ensure the uniform publication of observations and statistics; (4) to further the application of meteorology to aviation, shipping, water problems, agriculture and other human activities; (5) to promote activities in operational hydrology and to further close co-operation between meteorological and hydrological services; and (6) to encourage research and training in meteorology and, as appropriate, to assist in co-ordinating the international aspects of such research and training.

Organization. WMO has 185 member states and six member territories responsible for the operation of their own meteorological services. Congress, which is its supreme body, meets every four years to approve policy, programme and budget, and adopt regulations. The Executive Council meets at least once a year to prepare studies and recommendations for Congress, and supervises the implementation of Congress resolutions and regulations. It has 37 members, comprising the President and three Vice-Presidents, as well as the Presidents of the six Regional Associations (Africa, Asia, South America, North America, Central America and the Caribbean, South-West Pacific, Europe), whose task is to co-ordinate meteorological activity within their regions, and 27 members elected in their personal capacity. There are eight Technical Commissions composed of experts nominated by members of WMO, whose remit includes the following areas: basic systems, climatology, instruments and methods of observation, atmospheric sciences, aeronautical meteorology, agricultural meteorology, hydrology, oceanography and marine meteorology. A permanent Secretariat is maintained in Geneva. There are three regional offices for Africa, Asia and the Pacific, and the Americas. The budget for 2008-11 was $269.8 \mathrm{~m}$. Swiss francs.

Headquarters: 7 bis, avenue de la Paix, Case Postale 2300,

$\mathrm{CH}-1211$ Geneva 2, Switzerland.

Website: http://www.wmo.int

Email:wmo@wmo.int

Secretary-General: Michel Jarraud (France).

Publications. WMO Bulletin (quarterly); WMO Annual Report.

\section{World Tourism Organization (UNWTO)}

Origin. Established in 1925 in The Hague as the International Congress of Official Tourist Traffic Associations. Renamed the International Union for Official Tourism Organizations after the Second World War when it moved to Geneva, it was renamed the World Tourism Organization in 1975 and moved its headquarters to Madrid the following year.

The World Tourism Organization became an executing agency of the United Nations Development Programme in 1976 and in 1977 a formal co-operation agreement was signed with the UN itself. With a UN resolution on 23 Dec. 2003 the World Tourism Organization became a specialized agency of the United Nations.

Aims. The World Tourism Organization exists to help nations throughout the world maximize the positive impacts of tourism, such as job creation, new infrastructure and foreign exchange earnings, while at the same time minimizing negative environmental or social impacts.

Membership. The World Tourism Organization has three categories of membership: full membership which is open to all sovereign states; associate membership which is open to all territories not responsible for their external relations; and affiliate membership which comprises a wide range of organizations and companies working either directly in travel and tourism or in related sectors. In Feb. 2013 the World Tourism Organization had 155 full members, seven associate members and more than 400 affiliate members.

Organization. The General Assembly meets every two years to approve the budget and programme of work and to debate topics of vital importance to the tourism sector. The Executive Council is the governing board, responsible for ensuring that the organization carries out its work and keeps within its budget. The World Tourism Organization has six regional commissionsAfrica, the Americas, East Asia and the Pacific, Europe, the Middle East and South Asia-which meet at least once a year. Specialized committees of World Tourism Organization members advise on management and programme content.

Headquarters: Capitán Haya 42, 28020 Madrid, Spain.

Website: http://www.unwto.org

Secretary-General: Dr Taleb Rifai (Jordan).

Publications. Yearbook of Tourism Statistics (annual); Compendium of Tourism Statistics (annual); Travel and Tourism Barometer (3 a year); UNWTO News (4 a year); various others (about 100 a year).

\section{Other Organs Related to the UN}

\section{International Atomic Energy Agency (IAEA)}

Origin. An intergovernmental agency, the IAEA was established in 1957 under the aegis of the UN and reports annually to the General Assembly. Its Statute was approved on 26 Oct. 1956 at a conference at UN Headquarters.

Functions. To enhance the contribution of atomic energy to peace, health and prosperity throughout the world; and to ensure that Agency assistance and activities are not used for any military purpose. In addition, under the terms of the Nuclear NonProliferation Treaty (NPT), non-nuclear-weapon states are required to allow the IAEA to verify that their nuclear activities are peaceful. Similar responsibilities are given to the IAEA as part of the nuclear-weapon-free zone treaties in Latin America, the South Pacific, Africa and Southeast Asia.

Activities. The IAEA gives advice and technical assistance to developing countries on a wide range of aspects of nuclear power development. In addition, it promotes the use of radiation and isotopes in agriculture, industry, medicine and hydrology through expert services, training courses and fellowships, grants of equipment and supplies, research contracts, scientific meetings 